\title{
Disaster Information Literacy During Covid-19 Pandemic at a Christian School in Disaster-Prone Area
}

\author{
Petrus Ana Andung* \\ Communication Science Program of \\ Study \\ Universitas Nusa Cendana \\ Kupang, Indonesia \\ petrus_sdm@yahoo.com
}

\author{
Leonard Lobo \\ Pancasila and Civic Education \\ Program of Study \\ Universitas Nusa Cendana \\ Kupang, Indonesia \\ leolobo21@gmail.com
}

\author{
Silvania S. E Mandaru \\ Communication Science Program of \\ Study \\ Universitas Nusa Cendana \\ Kupang, Indonesia \\ frenymandaru@gmail.com
}

\begin{abstract}
East Nusa Tenggara (NTT) province in Indonesia, is susceptible to the threat of natural disasters such as earthquakes, tsunamis, floods, landslides, drought, whirlwinds, and fires. This means that all districts in the province are categorized as a disaster-prone area. The results of the preliminary study found that disaster hazards such as floods and whirlwinds were serious threats especially for the students of Rehoboth Christian Elementary School in Central Kupang Sub District, Kupang District. This article aimed to analyze the integration of disaster risk reduction materials into school learning during the Covid-19 pandemic at Rehoboth Christian School. This research used a case study approach and the data were collected using the in-depth interview technique and focus group discussion. The informants in this study were the teachers. The result showed that disaster information literacy at Rehoboth Christian School was implemented by integrating disaster topics, especially floods, and whirlwinds into the teacher's lesson plans. It found also that the school's strategy for learning during the Covid-19 pandemic was changing the learning method according to the demands of the new normal era. All learning processes were carried out using the home visit method. Teachers proactively visited students' houses to conduct short lessons and distribute learning materials.
\end{abstract}

Keywords-disaster, communication, mitigation, school, Covid-19

\section{INTRODUCTION}

East Nusa Tenggara is one of the provinces in Indonesia which is prone to disasters such as earthquakes, tsunamis, landslides, drought, whirlwinds, and fires [1]. The province is also known as a disaster supermarket. All districts in the province are categorized as disaster-prone, including Kupang District.

Landslide, whirlwinds, bush and land fire, floods, abrasion, drought, and earthquakes are some of the potential hazard disasters that threaten Kupang District. Therefore to establish resilient villages these threats need to be anticipated and taken care of. The Kupang district government has only facilitated two disaster-resilient villages with support from BNPB (National Disaster Management Authority). However, there are still no resilient village programs developed by the BPBD (Regional Disaster Management Agency) [2].
The result from the problem identification and analysis of the situation from the community service conducted by the Community Partnership Program at the Rehoboth Christian School found that disaster hazards such as flood and whirlwind were a serious threat to students of Rehoboth Christian School Kupang. The assessment concluded that an annual whirlwind struck the school, particularly during school hours. Below is the interview quotation with the principal of Rehoboth Christian School, Mariana Soares on the 20th of August 2019:

"Our school is located in the middle of the open field. There are no trees at all, therefore it is prone to the whirlwinds. The disaster struck our school annually. Our school was severely damaged when the whirlwind hit the area in December 2017 and January 2018. When it happened during the school hours, we stayed inside the class. The students are forbidden to go outside. The roofs are flying particularly from the houses near the school and some of the debris landed on the school yard".

Apart from the whirlwind, the location of the school is also susceptible to floods. The school is located near the river dividing the Mata Air and Oebelo villages and floods struck the area every year. The data from the report of Disaster Management Community Association suggested that the cause of the flood in Kupang district, especially in East Kupang district and Central Kupang district were deforestation, the surfeited structure of the soil, the settlement built near the riverbank, the shallow river, and the absence of disposal canal. Moreover, the government's efforts to mitigate and reduce disaster risks in this area were still very limited and did not provide a significant solution.

Communication is one of the least talk about aspect of disaster management in Indonesia. The increasing number of victims due to the disasters is caused by the lack of disaster information. Priyowidodo and Luik's research result argues that the limitedness of the mitigation information in disaster reduction creates agitation among the communities in responding to the disasters. It is obviously important that literacy on disaster or as it can be called disaster management communication is an urgent matter in the framework of disaster reduction [3]. 
The importance of literacy on disaster information is aligned with the government policy No. 64 of 2010, in the 14 and 16 articles that specifically mention that the mitigation of the disaster programs is both physical and non-physical. The non-physical mitigation of the disaster are communication and education of disaster management in the community [4].

In addition, the break of the Covid-19 pandemic creates agitation within the community of Rehoboth Christian School Kupang. The threat does not only come from the whirlwind and flood but also from Covid-19. Therefore, the article aimed to analyze the school's effort in integrating the disaster risk reduction materials during the Covid-19 pandemic. In addition, the article focused also to map the school's strategy to cope with the Covid-19 pandemic.

\section{DISASTER COMMUNICATION}

The concept of communication on disaster is quite new and unpopular even in the communication and disaster management areas. However, research on communication on the disaster has been conducted after the Aceh tsunami in 2014. Since then the understanding of the concept of communication on the disaster has improved and developed [5]. The term disaster communication is derived from the concept developed by Harold Laswell. He defines communication disaster as who says what, when, where, to who, through what channel, and for the purpose when a crisis or disaster struck [6].

Meanwhile, Anderson defines disaster communication as an activity of delivering information by the government or authorities to share information to communities on how to take on disasters. For that reason, disaster communication must be done in disaster prevention. Based on the definition, it can be concluded that disaster communication is a process of exchanging messages between the communicators in the cycle of disaster reduction: before, during, and after disaster struck [7].

There are two important aspects of disaster communication. The first aspect is the scheming before disasters struck and the second one is activities during emergencies or when disasters struck. Discussion on the activities before the disasters struck is connected with communication during the crisis [8].

\section{A. Disaster Risk Reduction in Indonesia}

According to article 1 in the law of the Republic of Indonesia number 24 of 2007, disaster shall mean an event or a series of events threatening and disturbing the community life and livelihood, caused by natural and/or non-natural as well as human factors resulting in human fatalities, environmental damage, loss of material possessions, and psychological impact [9].

Natural disasters as stated in law No 24 of 2007 are earthquake, tsunami, volcano eruption, flood, drought, whirlwind, and landslide. While disasters caused by other factors are technology failure, modernization failure, and epidemy. Social disaster, on the other hand, is caused by a range of incidents made by man including social, group, community conflict, and terror. Disasters are unpredictable to men and even advanced technology cannot make predictions.

Disaster reduction as stated in the law No 24 of 2007 is a series of effort which comprise development policy that includes disaster management, activities in relation to disaster prevention, emergency, and rehabilitation. Activities for disaster prevention is executed and act as an effort to reduce and prevent disaster.

The objectives of disaster risk management and reduction according to the government policy of the Republic of Indonesia No 21 of 2008 is to ensure a well-planned, integrated, coordinated, and comprehensive implementation of disaster management and reduction, and to provide protection from the disaster hazard. Moreover, in article 3 in the government policy, it is stated that the phase of disaster risk reduction includes pre-disaster, response during a disaster, and post-disaster. The management of disaster risk reduction is in the condition when a) there is no disaster struck and b) when there is a potential disaster that might strike. Disaster risk reduction is one of the stages of disaster management. Disaster risk management according to the government's policy of the Republic of Indonesia No 21 of 2008 is activities to reduce threat and vulnerability and to increase the community's ability to respond to disasters [10].

\section{B. The Importance of Communication Aspect in Disaster Risk Reduction Efforts in Indonesia}

Communication is one of the most essential aspects in all stages of disaster management. The importance of this communication can be shown through the essential functions contained in the communication itself. As stated by Effendy [11], communication has the main function to inform, to educate, to entertain, and to influence. Meanwhile, Lasswell argues that there are 3 essential communication functions, namely: the function of observing the surrounding environment, the function of connecting various components in the community in responding to the environment, and the transmission of the social heritage from one generation to the next [12].

\section{RESEARCH METHODOLOGY}

This qualitative research used a case study method. The data were gathered using in-depth interviews and focus group discussions. The informants in the research were 11 teachers from Rehoboth Christian School Kupang by using a purposive sample method.

The validity of this study was guaranteed using source and method of triangulation techniques. Source triangulation was done by matching answers among the informants. Meanwhile, method triangulation was carried out by confirming the information obtained in in-depth interviews with information that emerged during focus group discussions.

The data were analyzed by using Creswell's technique with six stages. The first stage was to prepare and process the data to be analyzed. At this stage data from the field was recorded in the form of an interview transcript. The next stage was to read all the data and do the reduction data. The process of data reduction was to filter the data according to the topic and the objective of the research. General ideas from the informants were recorded in order to recheck the depth of the information. The next step was to analyze the data deeper, using coding. Coding conducted based on the research topic. The coding process was helpful also in categorizing the data. The fourth step was to make a theme based on the categorization according to the research focus. At this stage, the inductive themes were chosen based on the research focus. 
A report in the form of qualitative narrative or descriptive was written at the fifth stage. The last stage was to make an interpretation from the result of the research [13]. The conclusion was drawn by holding on to the principles of qualitative research based on the inductive principle. Interpretation of data in narrative reports used symbolic interaction theory and relate it to relevant previous studies.

This research has limitations in terms of time due to the Covid-19 pandemic. Interaction with informants was relatively limited. There was no opportunity for direct observation. This research, like other qualitative researches, cannot be generalized.

\section{THE RESULTS OF THE RESEARCH}

\section{A. Integrating Disaster Information into Lesson.}

Based on the research results, it was found that Rehobot Christian School Kupang was committed to mainstreaming disaster issues through learning. The teachers made this happen by integrating disaster risk reduction materials into the lesson plan. Disaster topics were adapted to the types of threats faced by the school. As is well known, the threats that schools often face were floods and whirlwinds. Therefore, these 2 threats were the main topics that inserted into the lesson plans of teachers starting from grade 1 to grade 6 .

Efforts to integrate disaster material into the lesson plan were carried out in line with the results of assistance provided by the Community Partnership Program Implementation Team (PKM) of the University of Nusa Cendana. Prior to the lesson plan integration, teachers have been equipped with a number of knowledge and skills pieces of training regarding school-based disaster risk reduction efforts ranging from information campaign activities, disaster communication training, to workshops on integrating disaster information into learning.

Anike Kale as a teacher said that the integration of disaster content into the lesson plan happened due to the full coaching of the University of Nusa Cendana team. "We are grateful to the community service team who have provided us with tips in producing integrated lesson plans for disaster material. After we have been assisted, we committed to providing our children regarding disaster education because our school environment is in a disaster-prone zone, especially floods and whirlwind," said Kale during an in-depth interview.

The results of an in-depth interview with the Principal of Rehoboth Christian School, Mariajina Soares, confirmed that disaster education learning was integrated into two subjects, namely Natural Sciences (IPA) and Local Content (Mulok). "We have agreed with our fellow teachers that we teach disaster risk reduction for floods and whirlwinds for Science and local content. For the local content, the allocation is 1 hour for disaster material and the remaining 1 hour is for the subject of knowledge of the environment and social culture", she said.

A similar opinion was also expressed by another teacher, Yuliana Talan, during a focus group discussion (FGD). According to Yuliana, specifically for natural science subjects, the teachers inserted disaster information according to the main topics that had been outlined in the lesson plans so far. "For example, when discussing natural phenomena, it will discuss in more detail the 2 threats of flooding and whirlwind.
Meanwhile, the material changes in the lesson plans mostly occurred in the local content subject", said Talan.

After assisting by the community partnership program team, the teachers designed lesson plans that were adjusted to new learning habits during the Covid-19 pandemic. "If in normal learning 1 hour equals 35 minutes, then in this new normal era, we reduced it to 25 minutes. Thus, the lesson plans were designed to be shorter than before", said another teacher, Cejarlina Xavier.

Based on this information provided by the teachers, it can be seen that the learning has also been adjusted to the demands and directions of the government regarding the new normal era. The intensity and time of the meeting were reduced. If face-to-face class, 1 learning hour equals 35 minutes then in the new normal era due to the Covid-19 pandemic this was reduced to $1 \times 25$ minutes.

\section{B. Learning Method during The Covid-19 Pandemic.}

During the Covid-19 pandemic, teachers at Christian Elementary School Rehobot Kupang were changing their learning methods. Since the local government has not allowed face-to-face meetings in class, the school then applied the learning method with home visits.

"We do not do face-to-face learning in class. As teachers, we take the initiative to visit students' homes to provide materials so that they don't miss it too much", exclaimed Darius Nino.

Each teacher compiled a summary of the material and then duplicated it according to the number of students and then distributed it from house to house. While students whose parents have internet facilities or use mobile phones and or smartphones, learning was carried out by sending them via WhatsApp, a social media application. As stated by one of the teachers, Maria Elvira Mengo, during a focus group discussion:

"Not all of our children here have an android mobile phone. So, we had to visit them one by one to distribute the material and explain the subject for 15-30 minutes. If there are student's houses near by each other, we gather around 5-10 people in 1 house and then I give an explanation. Incidentally our area is in the green zone. But of course, we also apply health protocols. Children wear masks, wash their hands and keep their distance while sitting listening to my explanation. Especially for those with an Android mobile phone, I sent the material via WhatsApp, and I also made a video call to give explanations".

What Mengo said was also confirmed by other teachers who participated in the FGD. Ojorio Oliveira experienced the same thing. According to him, because he lives close to his students, he interacts more with them in small groups. "Since I live near to the school and there are many students around my house, I visit them every day and ask them to gather in small groups to teach them. Of course, we remain to obey health protocols to wearing masks, washing hands, and keeping their distance. Sometimes in one group, it consists of several children from a variety of grades. It's okay. I teach them all, "said Oliveira.

According to the Principal of the School, Mariajina Soares, this type of learning method was considered the most appropriate and relevant during the Covid-19 pandemic to 
avoid unwanted things. "Even though Kupang Regency is a green zone for 1 odd semester, it is according to the direction of the Government that no class meetings should be held during the Coronavirus Pandemic. So that all teachers met and agreed to change the learning method. Teachers were asked to actively visit their students. Meanwhile, for those students whose parents have an android mobile phone, the teachers communicate with them using WhatsApp or telephone to explain the material and also assignments."

\section{DISCUSSION}

Integrating disaster material into school learning plans can be understood as school-based disaster risk reduction (DRR) efforts. This kind of school-based mitigation was classified as an effective way to guarantee its sustainability. Mainstreaming disaster issues into learning materials in schools was beneficial not only to increase students' knowledge but for the surrounding as well. Students were prepared to play a role in conveying disaster information learned at school to their families and local communities [14]. In this context, children have been accustoming from an early age to recognize the condition of their surroundings, including the problems that arise such as the threat of flooding. Through the information received from the teacher, children would increase their capacity. Therefore, mainstreaming disaster issues through classroom learning could increase students' understanding of their role in disaster mitigation [15].

Disaster mitigation in the realm of education is very essential. The results of Hayudityas' research explicitly stated that students who have facilitated with disaster mitigation education showed an increase in disaster preparedness knowledge and skills [16]. In addition, the inclusion of disaster information in the lesson plan has a very real and significant impact on dissemination and practical action in relation to disaster mitigation [17].

It is therefore clear that capacity building through disaster information literacy to children in this school was a systematic and sustainable effort within the framework of disaster mitigation [18]. Only through disaster education can students be more prepared to face disasters [19].

What the teachers of Rehoboth Christian Elementary School have done was a step forward. How could it not? Disaster preparedness in the context of Indonesian society still leaves a lot of homework to do. Integrating DRR material into school lesson plans was not only useful in terms of reducing disaster risks as long as school residents were in the school environment. But it's also beneficial in the long run. Disaster awareness culture can be introduced earlier to students. A culture of disaster awareness for children can only be achieved through disaster education integrated into school learning [20].

As the results of research conducted by Suarmika and Utama proved that there was a relationship between the introduction of disaster information to students from an early age with disaster preparedness. If from an early age children were taught about disaster mitigation, these students would have resilience in facing disasters and love their environment [21]. Education which integrates environmental issues was proven to be able to improve students' critical thinking power to recognize and apply it in everyday life [22].
Teachers of Rehoboth Christian School Kupang in this context showed their commitment to disaster mitigation due to the increasing threat in the school environment. Therefore, the choices of material insertion by these teachers can be analyzed also from the perspective of Steven Wilson's message selection theory [23]. According to the view of this theory, the communicator's strategy in this case the teachers of Rehoboth school in selecting messages was adjusted to the circumstances around them. The threats of flooding and whirlwind that occur every year were the basis for teachers to integrate disaster material into their lesson plans. Thus, the selection of DRR materials aims to increase students' knowledge about the importance of paying attention to the surrounding environment in order to reduce the risk of disasters that can threaten lives at any time.

On the other hand, the threats faced by schools were not only due to floods and whirlwind but also related to the Covid19 pandemic. Therefore, the change in the teacher's strategy in carrying out learning by adjusting to new habits during the new normal era can be understood as part of improving school management. This means that learning during the new normal era demands good school management. Therefore, principal leadership was one of the keys to the smooth running of learning in the new normal era [24].

The school's decision to mobilize teachers to conduct home visit learning was an indication of the managerial functioning of the principal. Moreover, learning during the Covid-19 pandemic caused various problems such as communication problems, learning methods, materials, costs, and the use of technology. Therefore, one of the strategies in overcoming these obstacles was the importance of teacher creativity in planning lessons [25].

\section{CONCLUSION}

The conclusions that can be drawn are first, the efforts made by the Rehoboth Christian School Kupang in integrating disaster risk reduction material during the Covid-19 pandemic, was adjusting to the types of disaster threats in the school environment. Since floods and whirlwind were the main hazards, these two disaster topics were integrated into natural sciences and local content subjects. The integration of disaster material was carried out as an effort to disasters mitigation at school. The teachers intended that through such mitigation, their students would have a culture of disaster awareness from an early age. After being taught with disaster information, students were expected to pass the disaster knowledge to their peers, family, and the community around them.

Second, the school's strategy for learning during the Covid-19 pandemic was changing learning method according to the demands of learning in the new normal era. During the Covid-19 pandemic, all learning processes at this school were carried out using the home visit method. Teachers proactively visited students' houses to conduct short lessons and distribute learning materials.

This research has implications for the importance of nonphysical disaster mitigation that focuses on aspects of disaster communication and education in society. Mainstreaming disaster material into the lesson plans is very important to instill a culture of disaster awareness from an early age for students so that they have better disaster preparedness. 


\section{ACKNOWLEDGMENT}

This research was supported by Direktorat Riset dan Pengabdian Masyarakat, Kementerian Riset dan Teknologi/BRIN, Republic of Indonesia who has funded the implementation of PKM (Community Partnership Program) 2020.

\section{REFERENCES}

[1] N.M. Rysnawati, I.K. Sukarasa, and I.B.A Paramarta, Analisa Tingkat Bahaya dan Kerentanan Bencana Gempa Bumi di Wilayah Nusa Tenggara Timur (NTT), Buletin Fisika, vol. 18, No.1, February 2017, pp. $32-37$.

[2] Asqolani, Laporan Workshop Indikator Ketangguhan Daerah Kabupaten Kupang - Provinsi NTT, Kupang, unpublished, 2018.

[3] G. Priyowidodo and J.E. Luik, Literasi Mitigasi Bencana Tsunami Untuk Masyarakat Pesisir Di Kabupaten Pacitan Jawa Timur. Jurnal EKOTRANS, vo.13, No.1, January 2013, pp: 47-61.

[4] Government Rules/Peraturan Pemerintah No. 64 Year of 2010 tentang Mitigasi Bencana di Wilayah Pesisir dan Pulau-pulau Kecil.

[5] Rudianto, Komunikasi dalam Penanggulangan Bencana, Jurnal Simbolika, vo. 1, No.1, 2015, pp. 51-61.

[6] G. Rusch, Disaster Theory and Communication, No Year.

[7] N.B. Anderson, "Analysing Communication Processes in the Disaster Cycle: Theoretical Complementarities and Tensions", in R. Dahlberg, O. Rubin, and M.T. Vendel $\varnothing$, (Eds.), Disaster Research: Multidisciplinary and International Perspectives, London and New York: Routledge, 2016

[8] C. H. Botan, Strategic Communication Theory and Practice: The Cocreational Model, USA: Wiley Blackwell, 2018.

[9] Undang-Undang Republik Indonesia Nomor 24 Tahun 2007 tentang Penanggulangan Bencana.

[10] Peraturan Pemerintah Republik Indonesia Nomor 21 Tahun 2008 tentang Penyelenggaraan Penanggulangan Bencana

[11] O.U. Effendy, Ilmu, Teori dan Filsafat Komunikasi, Bandung: PT Citra Aditya Bakti, 2000.

[12] P. Manning, News and News Sources: A Critical Introduction, London, California, \& New Delhi: SAGE Publications, 2001

[13] J.W. Creswell, Research Design: Pendekatan Kualitatif, Kuantitatif, dan Mixed, Cetakan Ke-3, Terjemahan Achmad Fawaid, Yogyakarta: Pustaka Pelajar, 2013.
[14] Z. Septikasari and Y. Ayriza, "Strategi Integrasi Pendidikan Kebencanaan Dalam Optimalisasi Ketahanan Masyarakat Menghadapi Bencana Erupsi Gunung Merapi”, Jurnal Ketahanan Nasional, Vol. 24, No.1, pp. 47-59, April 2018, DOI:http://dx.doi.org/ $10.22146 / \mathrm{jkn} .33142$

[15] IW. Subagia, IGL. Wiratma, and IK. Sudita, "Pelatihan Mitigasi Bencana Alam Gempa Bumi Pada Siswa Sekolah Dasar Negeri 1 Pengastulan Kecamatan Seririt Kabupaten Buleleng Bali”, Jurnal Pendidikan Indonesia, Vol. 4, No.1, pp. 585-598, April 2015

[16] B. Hayudityas, Pentingnya Penerapan Pendidikan Mitigasi Bencana di Sekolah untuk Mengetahui Kesiapsiagaan Peserta Didik, Jurnal Edukasi Nonformal, vol. 1, No. 2, 2020, pp. $94-102$.

[17] Rubaidi, Pengarusutamaan Pengurangan Resiko Bencana (PRB) Berbasis Kurikulum Pendidikan Agama Islam, Al Izzah: Jurnal HasilHasil Penelitian, vol. 13, No. 2, 2018, pp. 272-285.

[18] A. Rahma, Implementasi Program Pengurangan Risiko Bencana (PRB) Melalui Pendidikan Formal, Varia Pendidikan, vol. 30, No. 1, 2018, pp. 1-11.

[19] M. Desfandi, "Urgensi Kurikulum Pendidikan Kebencanaan Berbasis Kearifan Lokal Di Indonesia”, Sosio Didaktika, Vol. 1, No.2, pp. 191198, Desember 2014.

[20] L. Qurrotaini, and N. Nuryanto, "Implementasi Pendidikan Mitigasi Bencana Alam Gempa Bumi Dalam Pembelajaran IPS SD," Trapsila: Jurnal Pendidikan Dasar, Vol. 2 No.1, pp. 37-44, Juli 2020.

[21] PE. Suarmika and EG. Utama, "Pendidikan Mitigasi Bencana Di Sekolah Dasar (Sebuah Kajian Analisis Etnopedagogi)", Jurnal Pendidikan Dasar Indonesia, Vol. 2 No. 2, pp. 18-24, September 2017.

[22] J. Ernst and M. Monroe, "The effects of environment-based education on students' critical thinking skills and disposition toward critical thinking", Environmental Education Research, Vol.10, No.4, pp.507522, 2004, DOI: 10.1080/1350462042000291038

[23] S.W. Littlejohn, Theories of Human Communication-7th ed, USA: Wadsworth, 2002

[24] N. Arafah and S. Bahri, "Peningkatan Human Capital Dalam Proses Pembelajaran di Era New Normal”, Jurnal Manajemen Bisnis, Vol.17, No. 3, pp. 425-444, Juli 2020

[25] M. Agustin1, RD. Puspita, D. Nurinten, and H. Nafiqoh, “Tipikal Kendala Guru PAUD dalam Mengajar pada Masa Pandemi Covid 19 dan Implikasinya", Jurnal Obsesi : Jurnal Pendidikan Anak Usia Dini, Vol. 5 No. 1, pp. 334-345, June 2021, DOI: 10.31004/obsesi.v5i1.598 